\title{
The Self-Legitimating Bureaucracy
}

\author{
Bureaucratic Justice. By Jerry L. Mashaw. New Haven and London: \\ Yale University Press, 1983. Pp. x, 227. $\$ 25.00$.
}

\section{Paul R. Verkuil $\nmid$}

The publication of Bureaucratic Justice ${ }^{1}$ fulfills the promise of Jerry Mashaw's earlier work ${ }^{2}$ and makes him a pivotal figure in the long overdue creation of an "internal" administrative law. While most scholars focus on the "external" administrative law generated by the interaction of courts and agencies, Professor Mashaw sets out to prove that the phrase "bureaucratic justice" is not an oxymoron:

The challenge is to admit the limitations of an externally oriented administrative law and yet to affirm a vision of administration that is subject to the normative evaluation and improvement that is the promise of legal discourse; to view the administrative process, like the judicial and legislative processes, as somehow in pursuit of justice and the general welfare; to see "administration," like "democracy" and "the rule of law," as a motivating ideal."

This profound and high-minded venture is still needed, despite the long history of administrative government in the United States, because of our preoccupation with "external" administrative law. Most influential lawyers and policymakers evaluate justice in the administrative context with notions of justice derived from the adversary system. It is as if, when asked the question what (or where) is administrative justice, they look for that particular lost coin under the proverbial streetlight of judicial process, not because the coin is there, but because that is where the light is. ${ }^{4}$ Mashaw's work ventures out to the dark edges of administrative justice to illuminate the quality of administrative decisionmaking in the bureaucracy itself. ${ }^{5}$ The author's broad familiarity with the subject and his

$\dagger$ Dean and Joseph M. Jones Professor of Law, Tulane Law School.

1. J. Mashaw, Bureaucratic Justice (1983) [hereinafter cited by page number only].

2. See Mashaw, The Management Side of Due Process, 59 Cornell L. REv. 772 (1974). This is a work of fundamental insight, which belongs in the company of such truly original works as Reich, The Neu' Properly, 73 Yale L.J. 733 (1964).

3. P. 14.

4. Mashaw playfully characterizes this tendency as "administrative law's sure instinct for the capillary." P. 19.

5. While Mashaw does not follow well-traveled roads, neither does he walk alone. Ernst Freund first offered the idea that administrative law should be concerned with the law produced by adminis- 
multidisciplinary method-he applies not only legal and economic analysis, but also the principles of political and organizational theory-is likely to interest a wide spectrum of readers.

Professor Mashaw's selection of the Social Security Administration's disability program as his object of study hardly needs justification. It is the Mount Everest of bureaucratic structures: One studies it because it is there. About $1,250,000$ initial disability claims are made annually, yielding 150,000 requests for hearings before administrative law judges (ALJs) and 10,000 filings for judicial review in the federal district courts. ${ }^{6}$ Over 5,600 state agency personnel and over $625 \mathrm{ALJs}$ are involved in deciding these claims. ${ }^{7}$ The size of the disability decision system is comparable to that of the entire federal court system ${ }^{8}$ and the average discounted present value of a successful disability claim is three times the statutory amount required for federal diversity cases. ${ }^{\circ}$

Since there are over four million beneficiaries of the disability program, ${ }^{10}$ and since these awards are often vital to the claimants' wellbeing, ${ }^{11}$ it is clearly in the interests of a just society to do as much as possible to get the decisions right. Mashaw's task is to move us further in that direction.

To understand what internal justice in a bureaucratic system such as the Social Security disability program might look like, the author describes three models of justice: bureaucratic or instrumental rationality; ${ }^{12}$

trative practice. E. Freund, CASES on ADMINISTRATIve LAw v (2d ed. 1928). Walter Gellhorn was the director of the staff of the Attorney General's Committee on Administrative Procedure, which produced a series of studies submitted to the Committee. See S. Doc. No. 10, 77th Cong., 1st Sess. iii (1941); S. Doc. No. 186, 76th Cong., 3d Sess. iii (1940). The Attorney General recommended enactment of legislation embodying the recommendations of the majority of the Committee. See 1941 ATT'Y Gen. ANN. Rep. 2-3. Kenneth Davis has looked closely at the problem of administrative discretion. See K. Davis, Discretionary Justice (1969) (arguing for new jurisprudence encompassing discretionary justice as well as more formal justice). Extreme public skepticism about the legitimacy of the administrative process has often placed those who would defend or explain bureaucracy on the defensive. Sep generally J. Freedman, Crisis and Legitimacy: The Administrative Process and AMERICAN GOVERNMENT (1978) (recurrent crises in administrative law due to fears that administrative agencies may lack legitimacy).

6. P. 18 .

7. Id.

8. In 1982, 206,000 civil cases were filed in the federal courts, see 1982 ANNUAL REPORT OF THE Director of ADMin. LAw, OfFice of THE U.S. Courts 92, with 860 federal judges (assisted by a like number of magistrates and staff) available to decide them, $i d$. at 35 . As early as fiscal year 1976 more than 625 ALJs disposed of 180,000 cases. See J. Mashaw, C. Goetz, F. Goodman, W. Schwartz \& P. VerkuIL, Social Security Hearings and Appeals xi (1978). There are currently 770 ALJs assigned to decide disability cases. Telephone interview with Office of Chief ALJ, Department of Health \& Human Services (Nov. 28, 1983).

9. Sep p. 18 (average present discounted value of successful claim is over $\$ 30,000$ ); 28 U.S.C. $\S$ 1332 (1976) (\$10,000 amount in controversy required to confer federal diversity jurisdiction).

10. Pp. 18-19.

11. Sep Mathews v. Eldridge, 424 U.S. 319, 342 \& n.26 (1976) (family of disabled worker typically has modest resources).

12. Pp. 25-26. 
professional treatment; ${ }^{13}$ and moral judgment. ${ }^{14}$ The first model emphasizes hierarchical review and values both accuracy and efficiency; the second emphasizes interpersonal relationships and values client service; and the third stresses independent decisionmaking and seeks fairness. While Mashaw finds aspects of all three models in the Social Security disability system, ${ }^{15}$ the book focuses on bureaucratic or instrumental rationality as the best source of an internal administrative law.

In the third chapter, Mashaw admits that even if we accept bureaucratic rationality as the appropriate model, the disability program is so rife with ambiguity, incoherence, and uncertainty that any search for bureaucratic rationality must begin by acknowledging that instrumental rationality in its pure form is unachievable. ${ }^{18}$ The statutory definition of disability itself provides little firm guidance to decisionmakers. A successful claimant must show not only a physical impairment but also an inability to perform any job in the national economy. ${ }^{17}$ The question of job availability is in most cases a hypothetical one: Could this person, who has established medical impairments and is out of work, compete in the national job market? This inquiry does not lend itself to consistent, rational resolution. Even the medical impairment question, while less speculative, is not easy to get right.

Another challenge to bureaucratic rationality is the dichotomous nature of the award system: Claimants are either winners or losers, designated as disabled or not, and entitled to full benefits or none at all. ${ }^{18}$ Since many cases are too close to call on a consistently rational basis, the system invites arbitrary decisionmaking. As the author understates it, "the line that Congress drew through the ability-disability continuum when establishing its eligibility standard cannot be precisely located."19

A further impediment to the emergence of a sound system of rational administration in the disability program is the extent and variety of over-

13. Pp. 26-29.

14. Pp. 29-31.

15. Pp. $34-40$.

16. Pp. $50-51$.

17. 42 U.S.C. $\S 423(d)(2)(1976)$.

18. P. 53.

19. P. 56. Various actors can nonetheless shift the line. Many state agencies have been more generous to claimants than the federal officials who set up the guidelines probably intended. See N.Y. Times, Sept. 12, 1983, at 1, col. 3 (New York and other states have begun to flout federal rules to help people retain Social Security disability benefits). Congressional amendments to the Social Security Act in 1980 made it more difficult to obtain benefits. See Pub. L. No. 96-265, 94 Stat. 441 (1980) (codified at 42 U.S.C. \$ 421(h) (Supp. V 1981)) (mandating review at 3-year intervals of all awards not classified as permanent). Congress is now considering legislation that would, over the Administration's objection, reduce the impact of the 1980 amendments. See N.Y. Times, Sept. 28, 1983, at 20, col. 4 (reporting House committee's approval of bill making it more difficult to cut off Social Security disability benefits). These oscillations raise further obstacles to uniform administration, especially when combined with congressional action at the case level, see infra p. 783. 
sight mechanisms it incorporates. There are potentially seven layers to the formal decision process, involving three species of officials: initial decision and reconsideration at the state level; the de novo decision of the ALJ and selective Appeals Council review at the federal administrative level; and federal judicial appeals to the district court, court of appeals, and Supreme Court. ${ }^{20}$ Congress concerns itself not merely with statutory governance of the disability program but with recovery in individual cases. As a result, members of Congress make over 100,000 contacts per year with the Social Security bureaucracy. ${ }^{21}$ Members of Congress see this casework function as part of their mission and encourage the bureaucracy to respond to it in a positive way.

Even the executive branch is not free to ignore individual cases. When the Reagan Administration's policy of tightening up on non-permanent disability awards resulted in a state agency's denying benefits to a Vietnam veteran who had received the Medal of Honor, critics attacked the denial as a typical instance of the callousness of a policy that had resulted in the termination of disability benefits for more than 350,000 people since March $1981 .{ }^{22}$ When a spokesman for the Social Security Administration announced reversal of that denial by a federal ALJ, all appeared to breathe a sigh of relief. ${ }^{23}$ We can only hope that the case does not establish an irrebuttable presumption in favor of recipients of the Medal of Honor. Given the conflicting forces at work in the process, however, no one can be sure.

Mashaw takes these obstacles to the realization of bureaucratic rationality in stride. In an admirable section labeled "exogenous goals," concedes that " $[t]$ he basic idea of instrumental rationality-first goals, then implementing action-may be reversed in the real world of administration."2s Rather than letting this realization frustrate his inquiry, Mashaw sees it as an invitation to shift from deductive to inductive analysis in the search for bureaucratic rationality. His assumption that "learning by doing will be fed back into the system"26 becomes an important principle of bureaucratic justice. Where the established branches -judicial, legislative, and executive-speak with institutionally competitive voices, some neutral institution must assimilate and rationalize the various messages. Thus, to the conventional system of checks and balances, the author adds a fourth participant: "The only change in the conventional

20. P. 18 .

21. P. 58 .

22. N.Y. Times, July 13,1983 , at 12 , col. 1 .

23. Id.

24. Pp. 60-61.

25. P. 60 .

26. P. 61 . 
model-and it is one that this essay insists upon-is that Bureaucracy has been admitted to the pantheon of institutional heroes."27 The boldness of this suggestion should not be overlooked. It implicitly rejects the classic condemnation of administrative agencies as the "headless fourth branch"28 of government and suggests that there is an affirmative role for bureaucracy as an institutional umpire of conflicting social directions.

To secure bureaucracy's place in the august company of the established branches is no small task. Mashaw concedes that the bureaucracy is subject to a fair amount of institutional incompetence, subversion, and arbitrariness. ${ }^{29} \mathrm{He}$ argues, however, that "the critic of institutions should . . . be concerned with the reasonableness of structures for decisionmaking that modify the pursuit of the ideal."30 This "second best" notion is used to introduce the body of organizational thinking that talks in terms of "satisfice" rather than "optimize" and emphasizes the limitations upon any institution's ability to conform to models of ideal decisionmaking. For example, political realities make two of the irrational forces upon disability determinations difficult to overcome. State-level decisionmaking, with deciders who are not under the direct control of the organization that pays the bill, introduces discord into the system, as do congressional inquiries into particular cases. Yet the force of politics-federalism and raw budgetary power-prevents the Social Security Administration from objecting seriously. Mashaw accepts this bureaucratic posture as a practical (though subversive) limitation upon the organization's ability to reform itself: "The critical question is to what degree the pursuit of organizational goals undermines the pursuit of program goals."

Mashaw emphasizes that the actual deciders in the disability system must ultimately assimilate and rationalize the conflicting signals of the other branches. The tension is between what he calls "systematic" rationality and "intuitive" rationality. ${ }^{32}$ The former seeks to make the bureaucracy more "controllable" by the use of clear rules and objective perform-

27. P. 58.

28. President's Comm. on Admin. Management, Report of the President's Committee ON ADMINistrative MANAGement 40 (1937). This characterization of administrative agencies has enjoyed a long and popular life. See Process Gas Consumers Group v. Consumers Energy Council, 103 S. Ct. 3556, 3558 (1983) (White, J., dissenting) ("[T]he independent agencies, once created, for all practical purposes are a fourth branch of the government not subject to the direct control of either Congress or the executive branch."). The usual corrective is to place the so-called independent agencies under the control of one of the "real" branches. See ABA CoMm'N ON L. \& ECON., FEDERAL REGULATION: ROADS TO REFORM 15 (1979) (advocating executive control of independent regulatory agency policymaking). In the wake of the Supreme Court's recent invalidation of a legislative veto, INS v. Chadha, 103 S. Ct. 2764 (1983), congressional (and perhaps even executive) control will have to be reassessed.

29. Pp. 64-74.

30. P. 65.

31. P. 69.

32. Pp. 75-77. 


\section{Bureaucratic Justice}

ance standards; the latter relies instead upon the moral judgments implicit in "creative" individual determinations. Mashaw's hunch is that intuitive rationality, which incorporates aspects of all three justice models, may be the best we can do. Yet he is unwilling to discard the idea of systematic rationality: "Some mixture of justice models and decisional techniques may be necessary to deal with the predictable failures of the systems engineers to rationalize fully bureaucratic implementation." ${ }^{33}$ The chapter closes on this intentionally ambiguous note.

Having placed bureaucratic rationality on the couch, Mashaw begins the analysis in chapter four by asking the efficiency question: How much are we as a society willing to pay for better disability decisions? Mashaw properly declares that the private market measure-how much an individual claimant is willing to pay to have a case decided-is an inadequate criterion for determining the appropriate level of societal investment in disability decisionmaking. The entitlement nature of the disability program presumes that society is not neutral about outcomes-it is pro-claimant in the sense that the government steps in to provide recovery for qualified individuals. Thus, as Mashaw notes, "[t]he basic rationale for the program is distributive justice, not allocational efficiency." ${ }^{24}$ This insight is important in analyzing all government programs, but it is fundamental to the disability program, where the beneficiaries are frequently in the lower-income brackets. ${ }^{35}$

Shifting the analysis from private costs and benefits to social ones does not, however, answer the question of how far society should go to decide the cases correctly. The current average investment in disability decisions is far less than their value- $\$ 500$ in decision costs for claims which average $\$ 30,000 .^{36}$ Mashaw concludes from this ratio that a considerable increase in public decision expenditures could be justified if the net social benefit were to increase. Reaching a conclusion on that point is important to his argument.

The first step is to recognize the differential effect of decisional errors in the disability program. Denials of benefits to people clearly disabled, or grants of benefits to those clearly not disabled, are more socially costly than grants or denials at the margin of disability. This proposition leads Mashaw to explore (and favor) rules for decision that "tend to eliminate [erroneous grants or denials] near the poles of the eligibility continuum."37 Mashaw argues that the objectification of eligibility standards through

33. P. 77. The decisional techniques he contrasts are the highly rule-bound state agency decisions based on written submissions, and the ALJ oral hearings, which are personalized or intuitive.

34. P. 81.

35. See supra note 11 .

36. Pp. $81-82$.

37. P. 85. 
rulemaking is the best way to avoid the high cost errors at the extremes. ${ }^{38}$ The idea is that the costliest errors are the product of the mistakes most susceptible to generic correction.

While the polar (or clear) cases are basic to any evaluation of the disability system's efficacy, they are likely to be far smaller in number than the marginal cases. Thus, while the mistakes in the clear cases have a much higher individual social value, mistakes in the marginal cases may have a higher aggregate social value. Because of their number, these cases are more likely to attract public and political attention. Any decision system must have a satisfactory way of resolving them before it can be vindicated, yet generic standards incorporated in rules are rarely adequate to the task. Nor can we decide difficult cases by the administrative equivalent of coin flips. ${ }^{39}$ As public "entitlements," there is an expectation that disability benefits will be administered on an individual basis, even where it is difficult if not impossible to make reliable distinctions among close cases.

The public perception of fairness is central to any critique of public decisionmaking. Mashaw accepts the perception of inequality in decisionmaking as a high social cost for a democracy. $\mathrm{He}$ is on very soft theoretical ground here, and most economists would quickly dismiss the notion that one can put any meaningful value upon the social costs or benefits of perceptions of unequal treatment in public decisionmaking. At this point in the analysis, therefore, it is necessary for Mashaw to argue that a concern for "process values" should supplement economists' traditional concern for the accuracy of decisionmaking. ${ }^{40}$

Mashaw's emphasis on the process value of equality leads him to question the propriety of adversarial disability determinations and to suggest other process values that should be taken into account in designing an appropriate adjudicatory scheme. ${ }^{41} \mathrm{He}$ seeks to transfer the positive attributes of the adversary process (which he claims supports "the basic liberal values of individuality, autonomy, and self-respect") to his system of bureaucratic rationality. ${ }^{42}$ This effort to create an individualized bureau-

38. Pp. 106-08; see Heckler v. Campbell, 103 S. Ct. 1952 (1983) (upholding SSA "grid" regulation for determining existence of jobs in national economy for persons of certain medical characteristics and abilities).

39. Mashaw states that we would be offended by coin tossing as a decisional process. P. 93. He rejects quota systems as inappropriate for the disability program, while recognizing the utility of such techniques in allocating FCC broadcast licenses or awarding government contracts. Pp. 87-88.

40. Pp. 88-89.

41. The other values Mashaw describes are transparency (by which he means openness), privacy, humaneness, appropriate symbolism, and participation. Pp. 88-97.

42. Pp. 88-89. Mashaw believes that the negative aspects of the adversary process, especially the inability to invoke it effectively without private resources, remove any clear reasons for preferring its use in the disability system. P. 96. 
cratic process makes his contribution to the procedural side of the public property debate potentially as significant as Charles Reich's contribution to the substantive theory of public entitlements. ${ }^{43}$ I applaud Mashaw's efforts. ${ }^{44}$ Nonetheless, to imbue a public decision model with the process values of the adversary system ${ }^{48}$ without duplicating that system's negative aspects, such as high cost and delay, is a formidable task.

In support of his claim that an alternative public decision model is required, Mashaw argues that disability decisions in a world of universal adversary hearings would founder on "interminable hearing delays or fiscal disaster."48 Given the inability of SSA deciders to compromise or settle cases, ${ }^{17}$ there is little prospect of a successful mass transference of the adversarial model to the disability program. A modified approach is needed. ${ }^{48}$

Mashaw stakes his case for a new model on the capacity of the bureaucracy "to make its internal structure and operation respond to a sensible set of demands for rational, fair, and efficient adjudication." 49 He identifies the two major deficiencies of the current disability process as informational and conceptual. Without information on the accuracy and fairness of decisions, the "unique claim of a bureaucratically rational system to our support"so is undermined. Similarly, "conceptual timidity" prevents the bureaucracy from embracing either the hearing process or some other process. This ambivalence subjects the decision system that emerges to the charge of second-class justice. ${ }^{\text {s1 }}$

Mashaw considers three reforms of the current system. One retains the

43. Reich, supra note 2 . Reich sought the "full adjudicatory procedures" of the adversary system to vindicate his public property rights. Reich, Individual Rights and Social Welfare: The Emerging Legal Issues, 74 YALE L.J. 1245, 1253 (1965). One scholar has openly questioned the appropriateness of employing a private-rights decision model (the adversary system) to vindicate a public-rights property concept. Sep Handler, Controlling Official Behavior in Welfare Administration, 54 CaLjF. L. REv. 479, 499-500 (1966) (power of welfare officials to thwart legislative programs "by simply doing nothing" is beyond "traditional judicial-type techniques of control"). Mashaw's implicit critique of Reich's assumptions is more sweeping.

44. Sep generally Verkuil, The Emerging Concept of Administrative Procedure, 78 Colum. L. REv. 258 (1978) (discussing history, normative requirements, and types of administrative procedures, and providing critical analysis of Administrative Procedure Act and other procedural statutes); Verkuil, The Search for a Legal Ethic: The Adversary System, Liberalisin and Bejond, 60 SoundINGS 54 (1977) (advocating recognition of connection among liberalism, pluralism, and the adversary system before exploring alternatives to these theories).

45. The case for the adversary model in prizate dispute resolution has been convincingly demonstrated. Spe J. Thibaut \& L. Walker, Procedural Justice (1975).

46. P. 192.

47. The SSA is not empowered to settle close cases, nor may it make partial awards, see p. 53, which can have the same effect as settlements. As Mashaw notes, settlement is the norm in most adversary systems. P. 192.

48. P. 193.

49. P. 194 (emphasis in original).

50. P. 195.

51. P. 197. 
current reconsideration process but supplements it with more face-to-face contact between the claimant and the deciders (especially at the state reconsideration stage) and more involvement of claimant representatives. Both mechanisms are designed to improve the flow of information to the decisionmakers, and thereby to increase accuracy and encourage the perception that the system is fair.

Both would also increase costs. Face-to-face encounters seem likely to increase the number of grants because the decider has both a better sense of the claimant's actual situation and a greater reluctance to reject those who appear in person. ${ }^{32}$ It is difficult to know beforehand which effect is stronger. If Mashaw's concern with the poorly developed file is justified (as it seems to be), there is as much likelihood that face-to-face contact will increase accurate decisionmaking as that it will increase merely sympathetic decisionmaking. ${ }^{53}$ Mashaw feels that representatives will also reduce the information gap (both from the claimant's and the system's perspectives), and that they will filter out frivolous claims ${ }^{54}$ and increase the claimant's sense of fair treatment.

Oral appearances and representation ${ }^{65}$ are classic ingredients of the adversary model. ${ }^{56}$ Their adoption would thus move the disability system in the direction of the adversary model, about which Mashaw has already expressed doubts. Perhaps for this reason he cautions that his proposal,

52. SSA experiments with interviews at the reconsideration stage indicate a tendency towards a higher level of awards. Sep pp. 199-200. The effects of face-to-face encounters may also help to explain the frequency of ALJ reversals of denied claims, see pp. 41-42, since ALJs are the first deciders actually to see the claimant in the present system.

53. The value Mashaw places on the decider's "sympathetic association with the claimant's situation," p. 202, is problematic. Sympathy in public decisionmakers is difficult to evaluate or control; it can be easily transformed into bias or even discrimination. Sep V. ThOMPSON, Without SyMPATHY or Enthusiasm: The Problem of Administrative Compassion 1-19 (1975).

54. P. 200. Mashaw expects a lot from government representatives when he suggests that they may serve to reduce frivolous appeals by counseling clear losers to accept defeat. Counseling would likely be better performed by representatives who must rely upon a claimant's recovery for their fee than by government-financed representatives.

55. Mashaw uses "representation" to include both legal and non-legal representatives whom the government would provide. Pp. 200-01. In suggesting that representatives need not be lawyers, he points with approval to the Veterans' Administration system of claims representatives. P. 201. That comparison, however, only opens a whole new area for study, i.e., how well does the VA claims system work? With over $\$ 13$ billion in disability payments awarded to over $3,000,000$ beneficiaries in fiscal year 1982, see 1982 ADM'R OF VETERANS' AFFAIRS ANNUAL REPORT 67, the VA system is of comparable magnitude to the SSA disability program. Much less is known about the VA's methods of awarding benefits, however, since it deals with a more homogeneous client base under its own congressional mandates and does not have its determinations reviewed by the courts. Under those circumstances, one should be cautious about endorsing the VA's representation scheme without further study of the entire system. Representational organizations like the American Legion or the Veterans of Foreign Wars, for example, are certainly not uncontroversial.

56. Sep Goldberg v. Kelly, 397 U.S. 254, 267-71 (1970). Mashaw's proposal to provide representatives at government expense, see supra note 55 , goes beyond the adversary-system ingredients which Goldberg declared are required by the due process clause. 
along with the two other non-adversary alternatives he discusses, ${ }^{57}$ should be tested before being fully implemented. He offers no method for selecting among these proposals but urges the Social Security Administration to experiment with them to determine which decision format best advances the decision values Mashaw has articulated. ${ }^{58}$ Under these conditions of uncertainty, it would take an heroic agency head to go forward.

Running through Mashaw's analysis is a yet more radical suggestion that would work a dramatic change in SSA disability procedures. He suggests that oral appearances and representation might be employed at the reconsideration stage of the state intake process and be used in lieu of ALJ hearings, and perhaps even of judicial review. ${ }^{88}$ This would make the SSA disability system look much like its counterpart at the Veterans' Administration, a prospect that poses additional questions. ${ }^{80}$ The opposition to such a proposal from the ALJ corps and the claimant population who rely upon judicial review would probably exceed those political forces that currently keep the states' decision role alive. Given the author's sensitivity to political realities, ${ }^{61}$ this proposal seems uncharacteristically utopian.

But perhaps I have read Mashaw too hard on that score. If more faceto-face contact and claimant representation at the state reconsideration stage can improve the quality of decisions, they may be worth exploring as an add-on to the present decision system, even though they are costly. Given the current relatively low average cost of decisions, any suggestion that raises the accuracy of decisions-even if it is more expensive to the decision system-may result in a net social benefit to the program and the public. $^{62}$ The critical element seems to be earlier and better development of cases to maximize the flow of information to and from the claimant, and thereby improve the correctness of decisions. Mashaw hopes that this effect alone will reduce appeal rates and increase claimant satisfaction. ${ }^{63}$

57. They are the use of medical examination panels and the use of multidisciplinary "workshops." Pp. 202-09.

58. P. 209.

59. Pp. 198, 209.

60. Sep supra note 55.

61. See supra p. 784.

62. Of course, there can be no automatic assumption that an increase in decision costs will bring about a comparable increase in accurate decisionmaking. There is no necessary relationship between the improvement in marginal outcomes and the increased decision expenditures. The point is only that one can afford to experiment, where decision costs are low, so as to measure whether these expenditures will increase accuracy of outcomes by more than their costs.

63. One concern with earlier adversary development of case files is its impact on the ALJ stage-assuming this stage is not eliminated. SSA ALJs are known for their "sympathetic" case development on behalf of unrepresented claimants. Making them more neutral and detached will not be easy, or even necessarily beneficial. Another possibility is to permit ALJs to make partial awards in close cases. This would require statutory authorization, whereas Mashaw's suggestions could be implemented administratively. Given the author's willingness to consider structural changes in the AL Js' 
The success of Mashaw's undertaking is not to be judged solely on the basis of the likely effectiveness of his proposed modifications to the existing SSA disability system. His role is entirely justified as an expository and explanatory one: Few lawyers have analyzed a complex decision on its own terms so well.

Mashaw's concluding words, born as they are of careful empirical analysis, have an inspirational quality: "My conclusion is that bureaucratic rationality-at least as practiced by SSA in the disability program-is a promising form of administrative justice. It permits the effective pursuit of collective ends without inordinately sacrificing individualistic or democratic ideals." ${ }^{\circ 4}$ These words express the hope that the goals of distributive justice can be met within the confines of the twentieth-century liberal state. But, as Mashaw observes, improvements to the disability decision system (and other bureaucracies like it) continue to founder on wrongheaded notions of external reform. ${ }^{85}$ Why is it that in order to legitimate bureaucratic decisionmaking we continue to resort to the single-minded use of judicial emulation and oversight? Or, as Mashaw puts it: "Must we strive forever within a conceptual framework that either denies its own underlying reality or compares it deprecatingly with institutional and legal structures that our substantive public policy long ago abandoned?"'s6

The importance of this observation can hardly be overstated. We have never satisfactorily harmonized substance and procedure as we have become increasingly concerned with matters of distributive justice. ${ }^{67}$ As a consequence, we still hamstring income-transfer programs with procedures that either frustrate, or fail to assist, achievement of the program's goals. This is Mashaw's message, but it has been lost even to some of those who endorse the substantive outcomes themselves, including the seminal thinker on this subject, Charles Reich. ${ }^{88}$ Until we are prepared to come to grips with the domination of adversarial thinking on public decisionmaking, all attempts to legitimate alternative models are doomed to failure. ${ }^{69}$

Legitimating an alternative model requires not only expanding the bu-

role and in judicial review, he should not regard the need for statutory change as a serious obstacle to reform.

64. P. 222.

65. Id.

66. P. 225.

67. See supra note 43. Chase argues that well into the first half of the 20th century legal scholars impeded the development of judicial control over the administrative system. W. CHASE, THE AMERICAN LAw School. AND THE Rise of AdMinistrative Government (1982).

68. Sep supra note 43.

69. See Verkuil, The Ombudsman and the Limits of the Adversany System, 75 Colum. L. REv. 845,846 (1975) (domination of adversary system has impeded development of ombudsman alternative). 
reaucratic rationality model that Mashaw endorses, but retaining nonadversarial characteristics in established programs currently outside of traditional judicial control. The VA disability program, for example, is constantly challenged by those who want to make its decisions subject to judicial review. ${ }^{70}$ Mashaw regards the VA solution-no ALJs and no judicial review - as more to be emulated than condemned. ${ }^{71}$ Unless the bureaucratic rationality model becomes a legitimate alternative mode of decisionmaking, however, the odds are much greater that the VA system will be forced to conform to the judicial control model than that other systems will break free of that model. For this reason, scholars like Mashaw, who have the necessary expertise and objectivity to undertake further study of the VA system, should do so before it succumbs to entreaties for judicial control. At a time when we are searching for a cure to the litigation explosion, empirical research with a healthy skepticism for traditional solutions should be broadly encouraged.

Mashaw has shown that bureaucratic rationality is a justice model that has a greater chance of ensuring correct decisions in disability cases than does a system of individual legal or constitutional rights administered by the courts. The effort has profound implications for the future of democratic government. In decrying "[t]he troublesome lack of a positive symbol of bureaucracy," contribution of Bureaucratic Justice is not symbolic; it is practical, analytical policymaking for a complex decision system of great significance to many Americans.

70. Decisions of the Veterans' Administration Administrator on questions of fact or law are not currently subject to review. See 38 U.S.C. \$211(a) (1976). But see Rabin, Preclusion of Judicial Revieu in the Pracessing of Claims for Velerans' Benefits: A Preliminary Analysis, 27 Stan. L. Rev. 905 (1975) (exploring arguments supporting judicial review of Veterans' Administration Administrator's decisions and favoring judicial review); F. Davis, Judicial Review of Benefits Decisions of the Veterans' Administration (1978) (unpublished report of Administrative Conference of the United States).

71. See supra p. 789.

72. P. 225. 
